\title{
Research on Effective Innovation of Ideological and Political Education on College Students from the Perspective of Mobile Internet
}

\author{
Haizhao Li \\ Shandong Technology and Business University \\ Yantai, Shandong, 264005, China
}

\begin{abstract}
In the era of mobile Internet, the most significant feature is that a large amount of data can be shared in an accurate way. The rapid development of mobile Internet has had a certain impact on the moral education of college students as well as on the concept and way of traditional education. This is both an opportunity and a challenge for college students' ideological and political education. Through the interpretation of the relationship between mobile Internet and ideological and political education of college students, this paper points out the influence of mobile Internet technology on college students in three aspects, that is it can expand the channels for college students to obtain information; change the way they communicate and their study habits. Additionally, the paper also offers the paths to innovate ideological and political education. It should enrich the ways and contents of education, build sound network platform for ideological and political education, emphasize the role of Internet in the education, strengthen the construction of teachers' team and enhance their quality, establish exchange platform for college students in mobile Internet ideological and political education and summarize the experience of ideological and political education in the era of Internet. By focusing on these six innovative strategies in ideological and political education in the era of mobile Internet, it can provide theoretical support for the effective innovation research of ideological and political education of college students from the perspective of mobile Internet.
\end{abstract}

Keywords—college students, ideological and political education, mobile Internet, effective innovation

\section{INTRODUCTION}

With the development of our country's economy and society and the improvement of people's living standard, people are more and more eager to pursue spiritual things. The arrival of the Internet era makes information spread at a rapid rate in a diversified manner. Opportunities and challenges coexist. The rapid development of information technology provides a certain opportunity and challenge for the ideological and political education for college students. In the new era, how to effectively research and innovate the ideological and political education is a hot topic. Therefore, it is imperative to discuss the practical innovation of college students' ideological and political education in the mobile Internet era.

This paper is the result of Research on the Innovation of Ideological and Political Education for College Students in Institutions of High Learning under the Background of "Internet Plus" (project No.: 18CSZJ08) of the social and scientific planning project of Shandong province(special project of ideological and political education in institutions of high learning)

\section{THE RELATIONSHIP BETWEEN MOBILE INTERNET AND IDEOLOGICAL AND POLITICAL EDUCATION ON COLLEGE STUDENTS}

The reform and development of mobile Internet technology is a profound revolution in the field of information technology industry, which brings many great changes to our life. In the era of mobile Internet, the most prominent feature is that a large amount of data can be used to enable people to share information in an accurate way regardless of time or place, which greatly meets people's requirements for convenience and initiative. The mobile Internet gives people the ability and vision to see the world as a whole. In the era of mobile Internet, people can make full use of massive data to analyze the personal preferences of the audience. In 2017, General Office of the CPC Central Committee and the General Office of State Council issued Opinions on Promoting the Healthy and Orderly Development of Mobile Internet, which is the first programmatic document on the development of mobile Internet in our country. The Opinions points out that it should promote the innovation and development of the mobile Internet, strengthen the driving and leading role of the mobile Internet, prevent the security risks in the mobile Internet, and deepen international exchanges and cooperation on the mobile Internet. High hopes are placed on the development of the mobile Internet. In the new era brought by technological changes, the way of ideological and political education for college students should also be changed correspondingly.

\section{THE INFLUENCE ON COLLEGE STUDENTS IN THE ERA OF MOBILE INTERNET}

\section{A. It can expand the channels for college students to obtain information}

In the era of mobile Internet, real-time and fast has become the main feature of this era. With the mobile Internet, people can greatly shorten the time of obtaining information and increase accuracy, which can make college students more efficient in their study and life. The mobile Internet provides more possibilities for the spread of information, making it more diversified and multifaceted. The contents for spread are also more colorful, changing from the traditional single text into pictures, sound and video with more diversified contents. College students also change their attitude towards information-obtaining from passive acceptance to active search, 
and the speed of obtaining information has been improving all the time.

\section{B. It can change the way college students communicate}

In the era of mobile Internet, the way college students communicate has undergone great changes. Traditional communication modes such as letter, telephone and telegraph have been fading away. WeChat, Weibo, QQ and other realtime communication tools emerging with the help of mobile Internet technology have been increasingly accepted by college students, greatly improving the efficiency of communication, adding convenience and promoting interpersonal communication and exchange. Meanwhile, in the era of mobile Internet, college students are provided with sufficient personal space to fully express their views, thus providing certain growth space for their personalized development.

\section{It can change college students' study habits}

The traditional study for college students is basically based on the knowledge taught by teachers in the classroom, with an undiversified learning approach and contents. However, the arrival of the era of mobile Internet has quietly changed the study and living habits of college students, enriched their learning methods and expanded their learning approaches. In mobile Internet era, information from around the world can concentrate on the mobile terminal and students can browse information from all over the world for entertainment and study according to their interests and preferences, thus greatly improving the convenience for college students' learning and changing their study habits.

\section{InNovative Strategies of Ideological and Political EDUCATION FOR COLLEGE STUDENTS BASED ON MOBILE INTERNET}

Mobile Internet has provided the ideological and political education with diversified development paths, making it more colorful and conducive to improving its effectiveness.

\section{A. It should innovate the approaches of ideological and political education and management for college students}

In the era of mobile Internet, efforts should be made to explore more ways for ideological and political education and management and to innovate its ways. It should improve the application skills and increase the frequency of mobile Internet in ideological and political education, advocate teachers to use mobile Internet in teaching and train students to use mobile Internet for ideological and political learning. In addition, it should enhance students' initiative in ideological and political learning through mobile phones and computers, so that they can learn and understand the related contents through multiple channels.

\section{B. It should enrich the ways and contents of education}

In the environment of mobile Internet, the overall teaching environment for college students' ideological and political education has been improving and optimizing no matter from the perspective of teaching or learning. With the rapid development of information technology, the rapid popularization of the application of the Internet enables teachers to have more teaching materials and students to have more learning materials. Under the background of the era of Internet, there are numerous websites for ideological and political teaching. With a single click of the mouse, teachers and students can search large amount of materials in a short time. The development of computer software technology in recent years has provided convenient conditions for people to obtain and process the data. The information technology environment makes it more convenient and rapid for people to obtain social information. People can easily get the hot information of any country in the world, which increases the close contact between schools and society. In addition, teachers' teaching and students' learning materials are constantly enriched. Now textbooks are not the only teaching materials for teachers to teach. Various types and a large quantity of teaching resources such as sound and video are increasingly used by teachers and students.

\section{It should build sound network platform for ideological and political education}

In the era of mobile Internet, people are able to search huge amount of information and have diversified communication modes and channels, which lays a certain foundation for the development of ideological and political education of college students. The use of mobile Internet technology can improve the effectiveness of ideological and political education to a certain extent. In the specific educational process in colleges, the network platform of ideological and political education for college students can be established which can be used to enable them to learn basic knowledge of ideological and political knowledge. The network platform is characterized by its inherent convenience and superiority, which avoids the tedious traditional teaching methods and makes the education more efficient. Although the mobile Internet platform can greatly improve the effectiveness of ideological and political education for college students, the excessively broad information resources on the Internet will inevitably attract students' attention to some extent, thus affecting the ideological and political education. Therefore, colleges should establish a sound supervision system to guide students' ideological and political learning through Internet platforms so as to ensure the quality of the teaching contents.

\section{It should emphasize the role of the Internet in ideological and political education for college students}

In the traditional cognition, ideological and political education for college students may only be limited in the classroom. However, in the era of mobile Internet, ideological education for college students can be carried out anytime and anywhere, making it more simple and effective. In practical teaching, colleges should attach great importance to the role of mobile Internet in ideological and political education for college students and give full play to its characteristics of concealment, pertinence, infectivity, interactivity and instance so as to get twice the result with half the effort for ideological and political education of college students. 


\section{E. It should strengthen the construction of teachers' team and enhance their quality}

In the aspect of ideological and political education of college students, teachers' own quality is an important factor affecting the education. Teachers are the leaders on the road of students' growth. It is very important for college students' ideological and political education to have a team of teachers with rich theoretical and practical teaching ability. Institutions of high learning should have consciousness, plan and purpose to enhance teachers' quality and strengthen the construction of teachers' team. The practical innovation of college students' ideological and political education in the era of mobile Internet encourages teachers to "go out" and look at the changes in modern society, so that the training mode of colleges and the educational mode of teachers can keep up with the pace of the times. In the era of mobile Internet, teachers should strengthen their own practical experience and learn from each other in order to better educate students in the future. Institutions of high learning should set up a team specializing in Internet ideological and political education and provide Internet technology-related training for workers with rich experience in it to fully combine science and technology with theory.

\section{F. It should establish an exchange platform for college students in mobile Internet ideological and political education}

The construction of exchange platform for college students' mobile Internet ideological and political education specifically refers to the establishment of official Weibo, post bar, WeChat communication group, QQ group, etc. It is helpful to improve students' ideological and political awareness by using mobile Internet, which can not only make students learn ideological and political knowledge in their spare time, but also improve the effectiveness of ideological and political education. Colleges can make use of their own resources to conduct more official publicity of ideological and political education and increase their publicity. Multimedia and other equipment can be used to make relevant educational videos and posters for ideological and political propaganda, which can be published to the official network platform of colleges. Students can exchange and communicate ideological and political knowledge through post bar, WeChat communication group, QQ group, etc. in their daily life. We can make full use of mobile phones, computers and other mobile terminals to strengthen their learning awareness of ideological and political knowledge and enhance their interest in it.

\section{G. It should summarize the experience of ideological and political education in the era of Internet}

In the era of mobile Internet, when carrying out ideological and political education, institutions of high learning should pay attention to summarize advanced ideological and political educational experience, pay attention to the refinement of essence and focus on the exploration of educational rules and the transformation of results. We should endeavor to spread educational experience in the form of theses in order to let more people study and make progress together and make the educational forms and contents be diversified, thus exploring the guidance mechanism by using mobile Internet for ideological and political education and realizing effective education. In view of the ideological problems found among college students, we should share the cases to let teachers and colleges better understand students' thoughts and at the same time we should conduct corresponding education to prepare for the future, establish a reasonable guidance mechanism and form a healthy mobile Internet education environment on campus.

\section{CONCLUSION}

With the development of China's economy and society and the improvement of people's living standards, people are more and more eager to pursue spiritual things. Social thoughts are more and more diversified. The ideological and political education for college students is facing complex and severe challenges. Relying on mobile Internet technology, people can know more about students' ideological dynamics and needs, and effectively improve the practical work of college students' ideological and political education so as to teach and spread educational information. It is also an important direction to carry out ideological and political education for college students in the future. In the new era, ideological and political education for college students should keep up the pace of the times and grasp the mainstream of the times. By doing so can we keep it efficient operation. In the era of mobile Internet, it is necessary to enrich the ways and contents of education, build sound network platform for ideological and political education, emphasize the role of Internet in the education, strengthen the construction of teachers' team and enhance their quality, establish exchange platform for college students in mobile Internet ideological and political education and summarize the experience of ideological and political education in the era of Internet, thus achieving the effective innovation of ideological and political education for college students in the era of Internet.

\section{REFERENCES}

[1] Fan Yingbo. On the Transformation of the Way of Ideological and Political Education for College Student in the Era of Internet Plus[J]. The Journal of Yunnan Administration College, 2017(3):76-80.

[2] Li Haiyan. On Discourse Identity Crisis and Measures of Ideological and Political Education for College Student in the Era of Internet[J].The Party Building and Ideological Education in School, 2017(24):50-52,65.

[3] Zhao Xiaodong, Li Ning. Research on People-to-People Care in Ideological and Political Education for College Student in the Era of Internet Plus[J]. Journal of Xingtai Polytechnic College, 2017,34(6):3538.

[4] Wang Weiguo. On the New Trend of the Development of Ideological and Political Education for College Student in the Era of Internet Plus[J] Ideological and Political Education Research, 2017,33(2):88-91.

[5] Wang Xiaoxiao, Liu Hongfeng. Analysis on the Ideological and Political Education for College Student in the Era of Internet Plus[J] Survey of Education, 2018,7(7):16-17,23.

[6] Huang Xiaomei, Deng Haiqing, Wu Ying. Research on the Innovation of the Ideological and Political Education for College Student in the Era of Internet Plus[J]. Journal of Hubei Correspondence University, 2017,30(15):1-3.

[7] Lou Xiaomin. On Measures and Suggestions: the Ideological and Political Education for College Student in the Era of Internet[J]. China Educational Technology, 2016(6):136-139. 
[8] Zhao Xiaoping. Research on the Practical Innovation of the Ideological and Political Education for College Student in the Era of Internet[J].
Vocational Education, 2014(4):58-61. 